\title{
India's economic reforms and challenges for industrialisation
}

\author{
Kalim Siddiqui ${ }^{1}$ \\ University of Huddersfield, Queensgate HD1 3DG, UK \\ e-mail correspondence: k.u.siddiqui@hud.ac.uk
}

\begin{abstract}
This study focuses on the issue of economic reforms and its impact on industrialisation in India. However, to understand this, it seems also crucial to analyse pre-economic reforms. In India, due to the prevalence of high unemployment and overburdened agriculture sector, the manufacturing sector becomes very important not only just in creating employment but also to boost manufacturing exports. The article examines existing literature on industrial sector in India and try to explain the challenges, it is currently facing. The 1991 economic reforms in India, removed tariff barriers to foreign investments and trade, with a hope that it will encourage foreign investors and ease burden on current accounts. The public sector and the role of the state in the economy was reduced and bureaucratic controls were dismantled, while at the same time the increasing the role of the market and private sector within the economy was strengthened. As a result, foreign capital investment and foreign exchange reserves improved. The study concludes that more than a quarter of a century has passed since pro-market policies were enacted, but such polices did not lead to rapid creation of employment opportunities. There has been no rapid growth of manufacturing sector and there has been no corresponding decline in the share in agricultural employment. Even the much heralded IT sector's dramatic expansion over the last two decades has provided jobs directly to less than a million people.
\end{abstract}

Keywords: Indian economy, manufacturing sector, economic reforms.

JEL classification: O20, O10, O25, F11.

\section{INTRODUCTION}

In 1991, India experienced the balance of payments crisis after nearly a decade of steady economic growth and stable macroeconomic performance i.e. increased investment and lower inflation rates and improvements in growth rates. In fact, the 1991 neoliberal economic reforms had been preceded by pro-business reforms and India had borrowed from the IMF after the second oil shock. Economic reforms continued and by the mid-1980s and government undertook further steps to de-regulate industry and trade. Economic liberalisation involves adopting more open trade and capital accounts policies. However, twenty-five years later, India managed to achieve high GDP growth rates, but at the same time very little or negligible employment growth had been a feature of the economy under neoliberal policies in India. Even stagnating or falling real wages, along with falling wage shares have not moved towards increased labour demand in the manufacturing sector.

\footnotetext{
${ }^{1}$ The author would like to thank John Smith and Hugo Radice for helpful comments and suggestions on earlier version.
} 
Soon after independence in 1947, India adopted mixed economic policies, despite the fact that the private sector was much larger than public sector, but the government exercised a large degree of control via "license raj" to a less regulated and more open economy with the private sector designed to play a more significant role than the public sector. The Indian government took a number of initiatives to enhance industrial and agricultural development, and also had focused on domestic demands and less relied on export-led growth. But the biggest failure was that it did not make any real impression on the country's huge unemployment problems. A number of measures were taken to stimulate and promote domestic industrialisation. However, the options for industrialisation began to be exhausted by the mid-1970s and the big industrialists saw that only collaborations and joint ventures, along with the availability of foreign borrowing and foreign markets, could further their interests. In addition, some high tech and IT companies found their interests lay with increased global market integration and gaining more access to foreign technology to improve efficiency and productivity, and enhance their growth. All these domestic changes led to the launching of neoliberal reforms, which began in the early 1980s and with major large-scale policy change in 1991 (Siddiqui, 2018; 1991). Industries in India tend to be dominated by a large number of small enterprises and a few large companies. Since the neoliberal was pursued, the India's engagement with the global economy has increased rapidly.

The study contributes by critically looking at not only the issue of growth rates, but also at the performance of the manufacturing sector. There seems to be a gap in the literature because most research has chosen to highlight the overall GDP growth rates of the Indian economy (Basu and Maertens, 2007), but little has been written about the industrial sector's importance, performance and near stagnation in overall job creation since economic reforms were launched in 1991. The aim of this study is also to provide a critical assessment of neoliberal reforms and its implications on Indian economy. The industrial sector has languished at around 16\% of GDP, which is much less than that of China or any other country at India's stage of economic development (Siddiqui, 2018; also 2016a).

The economic reforms of 1991 has provided to big boost to the rapid growth in the service sector and it seems that India is experiencing modernisation and economic re-structuring without going through the intermediate phase of a significant expansion of the manufacturing sector. The aims of the neoliberal policies adopted in 1991 were mainly: to remove the capital control on production, prices and market forces to influence investment and operational decisions; to allow international prices and market competition to influence economic decisions; and to liberalise the financial sector and remove controls over the banking sector (such as reducing state-directed credits and freeing the interest rates); and finally, to privatise public assets (Siddiqui, 2017a). Liberalisation of trade and investment rules was relaxed in India in 1991 to attract foreign capital and investment, and it was hoped that such changes would be able to attract relevant sectors to India from global value chain production, which increasingly serve as a location for world market production; however, there had been little success to date (Nayyar, 2006).

For the last more than two decades Indian economic growth reveals that this growth is unbalanced in terms of sector i.e. for nearly a quarter of a century the services have grown much faster than other sectors in the economy. Growth in the industrial and agricultural sector, which provides jobs for the majority of the work force, has been slower. Despite high growth rates annually of more than $7 \%$, developing economies such as India experienced a slight fall in their share of industry between 1998 and 2010. 
Their share of agriculture also continued to fall, while the service sector has expanded sharply since the early 1990s (Siddiqui, 2014a).

Despite experiencing faster economic growth for over twenty-five years, this has not benefitted agriculture sector in terms of raising farmers' incomes and has not diverted the unemployed rural people to find jobs. It has not created enough opportunity for the people working in agriculture to move out and find jobs in the industrial sector. This is because the industrial sector in India has experienced slow growth in employment creation i.e. less than $1 \%$ per annum. This structurally uneven growth, coupled with disproportionate policy and economic interventions, has led to the emergence of inter-sectoral differences, marked by agrarian crisis and slow industrialisation (Siddiqui, 2014a).

In 2013, nearly $60 \%$ of total employment was still in the agricultural sector, with productivity levels which generated incomes which were less than one-fifth of those in the rest of the economy (Economic Survey, 2014). Neoliberal policy did not offer any policy incentive for agricultural sector on which large number of people rely on for their livelihoods. In fact, if productivity in agricultural sector rises then this sector needs to employ less people. Therefore, the development of the manufacturing sector is crucial for overall productivity growth in the economy.

Despite the rapid success in the GDP growth rates the country has achieved since reforms, in terms of employment it still remains primarily an agricultural economy, accounting for nearly two-thirds of total employment and a fifth of the country's GDP. Between 1983 and 1993, employment increased by more than 2\% per annum. Then, from 1994 to 2006, the economy grew faster but employment growth decreased to $1.8 \%$ per annum. Since 2006 matters have become worse in terms of employment growth. Employment elasticity, which is a measure of the jobs that economic growth produces, had been $0.44 \%$ between 1999 and 2005 , while it declined to $0.01 \%$ for the period from 2005 to 2012 (Siddiqui, 2014a).

Therefore, for a fuller understanding of the performance of the industrial sector in India, we must examine at historical perspectives to compare this with past performance. According to the official data, during the pre-reform period between 1950 and 1960, the average annual growth rate in the industrial sector was $6.1 \%$, which declined to an average of $4.8 \%$ between 1960 and 1980. But the it increased to $8.2 \%$ per annum between 1980 and 1990 (CSO, 2014). Despite post-reform period (19922013), industrial growth increased to an average of around 7\% for India, while this figure was $11 \%$ for China for the same period per annum (CSO, 2014).

This article is organised as following. Following the introduction to this topic in section I, section II is briefly discusses the theoretical significance of the industrial sector. Section III analyses the relationship between agriculture and the industrial sector whilst sections IV and V focus on industrial growth during the pre-and postIndependence periods. Section VI then examines state vs. market policies, followed by a conclusion which summarises the findings.

Currently, the manufacturing sector contributes nearly $16 \%$ to India's GDP, provides jobs to $10 \%$ of the country's total workforce and produces nearly $80 \%$ of its total merchandise exports (Siddiqui, 2018). Although manufacturing sector is relatively small in comparison to India's whole economy, but there is a huge potential and this sector could play an important role in raising the productivity and in its development efforts.

It seems that the international financial institutions and also political elites in India have tended to focus largely on GDP growth and overlooked the fact that the 
economy needs to create more jobs (World Bank, 2006; Economist, 2007). Especially at a time when India has the largest number of young people of any country in the world, merely providing them with education is not enough. There is a need to find the real constraints on the growth of enterprises.

During the period from 1900 and 1946, the overall growth performance was negligible i.e. primary sectors' $0.9 \%$, while the secondary sector growth was only $1.1 \%$ annually (Maddison, 1995). In contrast, after independence, from 1950 to 2015, the primary sector in India grew at an average of $2.2 \%$ per annum, and the secondary sector at 5.3\%. Looking at individual decades, growth in the secondary sector was $6.7 \%$ in 1980-1990, and while it slowed down somewhat in the post-reform period (1991-2015), the secondary sector still grew at an average of $6 \%$ per annum (CSO, 2014; Siddiqui, 2014a). The past decades in India appear to have witnessed inadequate diversification of India's production structure away from agriculture and into manufacturing and somewhat premature rapid diversification into the service sector, (Siddiqui, 2015a).

The methodology to be followed here is derived from the aims of the study and comparisons of international statistics provide the main means of addressing the research questions and the objectives of this paper. Analysing pre-existing secondary data is the only possible way to obtain macroeconomic data. These include data from Indian government publications and from institutions such as the UNCTAD, World Bank and OECD.

\section{THEORETICAL SIGNIFICANCE}

Let us first define the concept of 'industrialisation', which refers to the shift in the pattern of a country's output and workforce towards industry. In the course of development, the industrial sector becomes proportionally more import than the primary sector both in terms of employment and revenue generation. The past experience indicates that the industrialisation seems to be very important in order to achieve affluence. Past experiences of developed countries suggest that to become prosperous a country needed to swing heavily towards expansion of manufacturing (Raj, 1986).

Nicolas Kaldor (1967) emphasised that industrialisation is a necessary stage of development, since it represents the development of productive forces and technology. In the developing countries industrialisation can play an important role as it saves foreign exchange by reducing imports and expanding employment opportunities; it lessens the burden on the agricultural sector, and also raises the overall productivity in the economy. The successful experiences of the industrialised countries also indicate that their success had been largely due to their strong manufacturing sector. As Kaldor (1967:54) argues that "The kind of economic growth which involves the use of modern technologies, and which eventuates in high real income per capita is inconceivable without industrialisation".

The expansion of industrial sector appears to be very important to the economic growth and well-being of the population of developing countries such as India. Kaldor (1967) identified what he considered to be the most critical issues in his 'Laws of Economic Development'. He sees the wider impact of the manufacturing sector as follows: 1) Higher growth in the manufacturing sectors could also lead to an increase in labour productivity; 2) Productivity in the non-manufacturing sector increases as the manufacturing sector expands; 3) Manufacturing is an engine of growth, not only because of higher productivity but also because of the external economies it generates, including forward and backward linkages; 4) As the manufacturing sector expands it provides job opportunities for the surplus labour in the agricultural sector, which 
ultimately reduces levels of unemployment and poverty (Kaldor, 1967). Job creation in manufacturing is related to the rate of growth of the output or value added. This, in turn, is linked with the rate of growth of wages relative to value added. Kalecki (1971) referred to the 'mark-up price' above the costs which the producers are able to charge or to the 'degree of monopoly' in the market.

Past experiences of a number of countries show that industrialisation is not merely an instrument of economic growth but also has an in-built mechanism for distributing the costs and benefits of growth. However, it seems that the opening up of domestic markets and free trade as strategies for industrialisation can be incompatible with the circumstances, particularly for late-industrialising countries. For example, South Korea is characterised by active state intervention in the economy and the accumulation process was sustained (Amsden, 2003). Protection for certain strategic industries by the state in South Korea was considered necessary in order to bring about a situation where integration with the world economy would lead to the development of industries and expansion in employment domestically.

During the last four decades, the rapid economic transformation of the East Asian countries has become the most important development in the world economy. For instance, initially the development in Japan, then South Korea and most recently in China has been the most spectacular and the most widely discussed (Siddiqui, 2009; Das, 2006). However, proponents of 'outward-looking' industrialisation policy overlook the differences among the East Asian countries that successfully followed this policy (Siddiqui, 2013). Japan and South Korea had almost no foreign direct investment capital flows, while the economies of East Asian countries like Hong Kong, Singapore (Siddiqui, 2010) and more recently, China, have been dominated by inflows of foreign capital (Sen, 2007).

For instance, when we compare with China, both countries had roughly same levels of industrialisation in the 1950s; India, rather, at this time had slightly more developed industries than China, but by 2015 China became the world's second-largest manufacturing country, while India ranked tenth, producing one-quarter of China's industrial output (Nagaraj, 2017) At present, India and China are among the fastest growing economies in the world. Despite the differences in the performance of the industrial sectors in both countries, industry could have a vital role to play in improving the economy, productivity and living conditions of their people. These two countries together constitute nearly $40 \%$ of the world's population. Therefore, what happens to China and India is of great importance to academics and policy makers (Siddiqui, 2009).Manufacturing activities can be regarded as a critical engine of growth for the economy. The development of the manufacturing sector is seen to be crucial in order to allow India to expand supply and reduce the risk that the current growth spurt might not be sustainable because of supply side constraints (Economist, 2007).

In the light of a recent study by Dani Rodrik (2016), there is a need to revisit the question of industrialisation, which is still very important for creating employment, diversifying the economy and removing the low productivity workforce from agriculture. However, according this study, the increased global integration and liberalisation has led to de-industrialisation in some regions. It is very important for a country like India to draw lessons from such a potentially adverse impact, which could be a huge destabilising factor in India. As Rodrik (2016:2) argues: "With some exceptions, confined largely to [East] Asia, developing countries have experienced falling manufacturing shares in both employment and real value added, especially since 1980s. For the most part, these countries had built up modest manufacturing during the 
1950s and 60s, behind protective walls and under policies of import substitution. These industries have been shrinking significantly since then. The low-income economies of sub-Saharan Africa have been affected nearly as much by these trends as the middleincome economies of Latin America - though there was less manufacturing to begin with in the former group of countries...Developing countries are turning into service economies without having gone through a proper experience of industrialisation. I call this premature deindustrialisation."

\section{RELATIONSHIP BETWEEN AGRICULTURE AND INDUSTRY}

Agriculture and industry are closely inter-related, as the performance of one sector affects that of the other. The agricultural sector provides raw materials for industries and also offers an important market for locally produced manufacturing goods (Siddiqui, 2015a). Earlier discussion of the relationship between industrialisation and agriculture by Prebisch, Lewis and others focused on agricultural growth as a very important stimulus towards rapid industrialisation through transfer of savings. Lewis (1954) emphasised that the agricultural sector plays an important role as a supplier of surplus to industry. He suggested that the supply of surplus from the agricultural sector and also a constant supply of workers at low wages could be important factors towards industrial growth. Lewis (1954) argues that: "Industrialisation is dependent upon agricultural improvement; it is not profitable to produce a growing volume of manufactures unless agricultural production is growing simultaneously. This is also why industrial and agrarian revolutions always go together. Economies in which, agriculture is stagnant do not show industrial development" (Lewis, 1954:433).

Demand-side constraints and how these might impact on the demand for industrial product in the domestic market was another major issue. Kaldor (1967) focused specifically on the demand-side problem of industrial growth. According to him, the growth of agricultural surplus is an essential condition to raise the purchasing power necessary for sustaining industrial growth. Kaldor suggests that to sustain industrialisation the terms of trade between these two sectors should be in favour of agriculture. He further argues that agricultural productivity should be improved with the help of technology to increase surplus and that would keep the food prices low, while increasing the demand for industrial goods (Kaldor, 1967).

The Prebisch-Singer model emphasises that elasticity is generally greater for manufacturing than primary products. Prior to industrialisation a country obviously had to resort to importing industrial goods and exporting primary goods. Prebisch-Singer OR Prebisch and Singer also noted that the terms of trade in the past had often been against the interests of primary producers, meaning that under such circumstances a country's imports of industrial goods would be limited by its export earnings (Siddiqui, 1998). Thus, the dependence on importing industrial goods and modern technology would limit the possibilities of income growth. Under such circumstances, an import substitution policy would help the country to relax these constraints by economising on the use of foreign exchange (Singer, 1987).

Moreover, the financing of the investment required by industries could be done by transferring funds from the agricultural sector. The terms of trade were favourable in the agricultural sector in India, especially in the period from the 1960s to the 1980s, but the outcome was that neither the industrial sector nor the rural poor benefitted from this. The Indian government refused to tax rich farmers and large land owners to raise revenue. As a result, the rural rich siphoned off most of the surplus, since they did not 
pay any direct taxation and deprived the rural poor by undermining land reforms and not implementing minimum wages (Siddiqui, 2015a).

It appears that in the absence of significant improvement in the rates of growth in agriculture, in the near future there will be greater willingness to use imports to dampen down rising prices and place constraints on the supply of raw materials. K. N. Raj has commented: "Private consumers demand in a country such as India depends to a large extent $[\ldots]$ on how things go in the agricultural sector. If output and income in this sector are rising rapidly, consumer demand for both agriculture and non-agricultural product can also be expected to increase rapidly, the latter being even more than the former since higher proportions are generally spent on non-agricultural products as levels of income rise (Raj, 1986: 225).

The share of agriculture in terms of GDP in 1950-51 was $56.70 \%$, while its share in total employment was $85 \%$ for the same period. The share of agriculture in GDP fell sharply thereafter, and by $2015-16$ it was $13.05 \%$, while the fall in the share in the agricultural employment was much slower $(55 \%)$, and more than half the population still depends on agriculture for their livelihood, as shown in Table 1.

Table 1. Share of agriculture in GDP and employment in India, between 1950-51 and 2015-16.

\begin{tabular}{lcc}
\hline Year & $\begin{array}{c}\text { Share of agriculture in GDP at } \\
1999-2000 \text { prices }(\%)\end{array}$ & $\begin{array}{c}\text { Share of agriculture in } \\
\text { employment }(\%)\end{array}$ \\
\hline $1950-51$ & 56.70 & 85.0 \\
$1960-61$ & 52.48 & 77.3 \\
$1970-71$ & 46.00 & 63.9 \\
$1980-81$ & 40.00 & 60.0 \\
$1991-92$ & 34.04 & 58.1 \\
$2001-02$ & 25.18 & 57.3 \\
$2011-12$ & 14.00 & 56.0 \\
$2015-16$ & 13.05 & 55.0 \\
\hline
\end{tabular}

Source: National Sample Survey, various years, Central Statistical Organisation, Government of India, New Delhi

\section{INDUSTRIALISATION DURING THE COLONIAL PERIOD: 1757-1947}

During the colonial period, modern industrial development in India was only carried out by the private sector because state investment in the industrial sector was dismal (Siddiqui, 1996). Academics have already discussed the $19^{\text {th }}$ century impact of the British rule on Indian industry, especially the decline of the indigenous handicraft manufacturing sector (Dutt, 1902; Anstey, 1957; Thorner, 1962; Siddiqui, 1990). However, the neoclassical economists choose to ignore past economic realities, failing to say anything about how a handful of metropolitan countries controlled global resources and created a new international division of labour to further their economic and strategic interests (Chang, 2010; Reinert, 2007; Siddiqui, 1990).

British rule in India lasted for nearly 200 years. In terms of policies, it could be divided into three phases. The British's own class forces changed which led to changes in policies in India. The first phase (1757-1813) could be termed as the merchant capital period. During this period, merchants enjoyed monopoly trade between India and Europe, dominated by the 'East India Company', a British trading company based in the City of London. During the second phase (1813-1890), the trade monopoly of the 'East India Company' was abolished and policies in India were enacted to promote British industrial capital. In the third phase (1890-1946) was led by the interest of the finance capital and it was dominated by the export of capital from Britain to India for mining, 
tea plantations, railways etc. During this period British investment in India was onesided and did not stimulate overall industrial growth in India. Moreover, vast funds were spent for unproductive purposes such as the military, colonial administration, etc. while productive activity was confined largely to the extraction of raw materials. Even the banks and insurance companies were developed to stimulate the production of raw materials (Siddiqui, 1990:65).

The primary method of surplus extraction in India was in the form of land revenue levies. Initially the East India Company's trade was based on the import of Indian piece goods (such as muslin and calico), spices, indigo and silk. The trade was financed by the export of Treasury bullion from Britain. However, after the occupation of Bengal, the Company gained ultimate control of resources beyond their wildest dreams which they were able to exploit without having to pay but were able to sell at full price. This could be achieved by treating the entire revenue of India as gross profit (Bagchi, 1976). As Habib (1984) argues, following the Plassey victory in 1757 i.e. occupation of Bengal: "enormous individual fortunes were made, [...] followed by a continuous extraction of wealth, through taxation, monopoly and corruption" (Habib, 1984: 5).

The benefits that the industrialised countries derived from their colonial markets are ignored in the mainstream arguments (Krueger, 1987). The Colonies provided markets, supplied raw materials and cheap labour. The economic policies were formulated in the Colonies to suit the metropolis. For Britain, for example, the access to colonial markets provided assured markets for their manufactured goods but at the same time British protectionism ensured that Indian manufactured goods could not be sold into British markets (Siddiqui, 1990). The supply of cheap raw materials from India minimised inflation in Britain. Until the end of the $19^{\text {th }}$ century, nearly half of British exports consisted of cotton textiles, destined chiefly for India and China, ironically at the same time that these two countries were themselves experiencing deindustrialisation, massive unemployment and poverty (Siddiqui, 2009). The international division of labour was created with the metropolis producing manufactured and exported high-end goods while the Colonies served as a source of raw materials and primary commodities.

For the Colonies, the notion of 'comparative advantage' meant that they had to specialise in the production and export of raw materials. In fact, the adoption of such policies led to the perpetuation of mass poverty and famine in India for the whole of the $19^{\text {th }}$ century and first half of the $20^{\text {th }}$. India proved to be useful to Britain as the surplus extracted from this colony was used to settle its deficits with the other industrialised countries whose goods it had imported. During the period from 1900 to 1946, India experienced near stagnation in per capita income, while GDP growth was minimal. Maddison estimated that growth in national output was only $0.81 \%$ per annum, whereas growth in per capita was dismal, being just $0.04 \%$ per annum (Maddison, 1995). In contrast to this, in the second half of the $20^{\text {th }}$ century the annual growth in GDP was $4.2 \%$ and per capita income was $2.1 \%$.

Thorner (1962) analysed the issue of the destruction of handicrafts in India. He defined de-industrialisation as either a decline in the proportion of the working population engaged in the industrial sector or a decline in the proportion of the total population dependent on the industrial sector. Thorner argues: "India's national handicrafts have declined sadly from their pristine glory. This falling-off, however, was not a phenomenon peculiar to India but a worldwide development affecting countries at 
different times. The ruin sooner or later of the old style craftsmen, was an integral part of the Industrial Revolution as the coming of the factory system" (Thorner, 1962: 70).

However, it seems that such an argument ignores that industrial development in Britain as a colonising power and India as a colonised country had taken place in different circumstances. For example, in Britain, the traditional industries such as handicrafts faced destruction in the $19^{\text {th }}$ century due to the rapid development of industries. People lost jobs in the traditional industries but the jobs created in the modern industries were much higher than those which were lost. However, the experience in the Colonies such as India was quite different. The British government used protective measures not only during the early years of the Industrial Revolution but right the way through until the 1840s; however, no such protective measures were available for Indian industries. In India, handloom weaving and hand-spinning constituted the largest handicraft industries, employing a large number of people. Therefore, their destruction had a very depressive effect on the whole economy (Siddiqui, 1996; Bagchi, 1985). As Bagchi (1976: 154) observes: "Within India herself, when de-industrialisation drove labourers to seek their living in agriculture, they faced highly imperfect market, the most important complementary asset, land, being already concentrated in the hands of landlords".

The growth of the British textile industry practically wiped out India's cotton goods markets in Britain, and even began to seriously threaten Indian industries in their home markets. For instance, Britain's textile goods exports rose from 0.8 million yards in 1815 to 45,000 million yards in 1830 ; this increased again to 51.78 million yards in 1835 and had reached 100,000 million yards by 1839. Cotton twist increased from just 8 IBs in 1814 to 4.56 IBs in 1828 and 10.81 million IBs by 1839 . In terms of monetary value, Britain's total cotton exports to India amounted to $£ 2.29$ million in 1839 whilst cotton twist was another $£ 0.64$ million. But by 1855 these figures had risen to $£ 5.40$ million and $£ 1.27$ million, while India's manufactured cotton exports declined. For example, between 1794 and 1804 India's piece goods exports were $£ 2.42$ million per annum. Later, this figure fell sharply to $£ 0.69$ million by 1849 (Anstey, 1957; Dutt, 1902). Similar trends could be seen in other areas of Britain's exports to Indian markets with iron bars, machinery, bolts, cutlery, guns, and glasses all having rapidly increased. This led to the 'de-industrialisation' of India. As Habib argues that "The urban decline, initiated by the diversion of surplus from the Indian ruling classes to the Company, spread quite naturally wherever the East India Company's sovereignty extended. It was compounded many times over the urban unemployment by English manufacturers. This urban decline seems not only to have been in relative terms (percentage of urban population to total), but in absolute terms as well" (Habib, 1975: 38).

The surplus was not invested domestically in India and did not create new jobs. As a result the Indian economy became subservient rather than sovereign in terms of policy matters. The fruits of its labour were systematically transferred to Britain or its new colonies of white settlers. Economic development was hampered by the removal of 'surplus', high land rents and tribute charges, and also by the destruction of the Indian capitalist class meaning that they were unable to invest. A densely populated country like India was drawn into the orbit of exploitation in the mid- $18^{\text {th }}$ century and later on, in the interest of British industry, India was utilised as a huge market for their products. Moreover, as Bagchi (1985) argues: "Competition from the foreign cloth led to the unemployment among handloom weaver, where wages declined" (Bagchi, 1985: 101). The huge increase in the cultivation of the opium, indigo, tea and jute led to the decline of land available for the cultivation of food crops. As Bagchi notes about the changes in 
the production structure that, "The trade in opium illustrates how advanced capitalist countries have in the past moulded the production and consumption structure of the whole subcontinents and have impeded their progress" (Bagchi, 1985: 102).

\section{INDUSTRIAL PERFORMANCE FROM 1947 TO 1990}

On the eve of independence in 1947 modern large scale industries and mining contributed just $7 \%$ of India's GDP, while small scale industries accounted for $10 \%$ and the agricultural sector $49 \%$ and services and construction $34 \%$. Total employment in the industrial sector was just 2.9 million people, which amounted to less than $2 \%$ of the total workforce. In contrast to this, the small industries employed a much higher proportion, some $7 \%$ of the workforce, while nearly $72 \%$ of the Indian workforce was employed in agriculture; services including construction employed $18.7 \%$ of the total workforce. Cotton and jute were among the main modern industries established in the early $20^{\text {th }}$ century in India (Siddiqui, 1996).

In fact, even this lop-sided industrialisation that India had managed to achieve under colonial rule was closely linked to British industrial and financial interest rather than sovereign industrial growth. The anti-colonial struggle in India had a clear vision concerning the need for improvement in the material conditions of life of the people. Post-independence India the state played an active role, which was seen as beneficial by the industrialists who came up with 'Bombay Plan', which suggested that public investment was needed in key industrial sectors to boost the economy. The policy was aimed at developing basic industries via government planning, while the bulk of the economy remained in the hands of private enterprises. India's first Prime Minister, Nehru, was impressed with Soviet economic planning and the USSR's rapid capital intensive industrialisation. It was said that such strategy posed a constraint on resources available for agricultural development. For example, government spending on agriculture and irrigation decreased from $34.6 \%$ in the first Five-Year Plan to $17.5 \%$ in the second Five-Year Plan, with investment in heavy industries being prioritised during this later period. The second Five-Year Plan in 1956 was launched to build 'heavy industries', which was seen as being essential for the country's long term industrial growth.

The "inward-looking" dirigiste economic strategy adopted in pre-reform period in India was seen as the most suitable option by the ruling elites. Also known as the 'import substitution' strategy option the public sector was expected to take a leading role in the development process. However, such policies were criticised by neoclassical economists as inefficient, promoting delays and corruption. The proponents of neoliberal reforms argue that: "Rather than adopting the classic Asian strategy -exporting labour-intensive low-priced manufactured goods to the West- India has relied on its domestic market more than exports, consumption more than investment, services more than industry, and high-tech more than low-skilled manufacturing" (Das, 2006:2). The aim was to remove serious gaps in the production structure. Due to the long gestation period, private investors saw such investments as high risk and also lacked funds.

On the other hand, the government was determined not to tax the rich. Therefore, for public sector investment funding, the government relied on foreign aid, deficit financing and indirect taxation. As a result, for example, the share of indirect taxes to the total tax revenue increased from $61.9 \%$ in 1955 to $70.7 \%$ in 1966 . Both indirect taxes and deficit financing were regressive, meaning that they had a dampening effect on income for the majority of people. As a result, the domestic market for mass 
consumer goods did not increase. Hence, further initiatives for investment and industrialisation by private investors were undermined (Raj, 1986).

Between 1951 and 1965, the annual average industrial growth was 7\%, which was much higher than anything that had been seen in the past. There was also a notable shift as the importance of traditional industries such as jute and cotton declined, while modern industries such as machinery, engineering, chemicals, rubber, pharmaceuticals, power and steel became more important. However, the industrial growth also coincided with huge increments in foreign debts and foreign aid, which meant that industrialisation in India was not financially self-reliant. Moreover, Indian industries did not allocate much money for research and development, which resulted in increased reliance on imported technology and foreign corporations. Although pre-reform industrialisation in India was impressive in terms of growth, it failed to make any dent on growing unemployment (Raj, 1986).

Industrial stagnation marked the period from the mid-1960s to the end of the 1970s. Then in the early 1980s, the government took various measures to promote businesses and as a result the economy grew faster in comparison to previous decades, but the country relied heavily on foreign borrowings. The fiscal deficit and foreign debts had increased to high levels by the end of the 1980s. As a result, the debt service ratio had become untenable.

\section{ECONOMIC REFORMS OF 1991 AND INDUSTRIAL GROWTH}

The Gulf War in 1991 added to the India's fiscal crisis and a further crisis was just waiting to happen. The government decided to accept an IMF loan and under the Finance Minister, Manmohan Singh, it began to implement neoliberal economic reforms. As a result, industrial licensing was discarded and import tariff rates were sharply reduced. The IMF and World Bank supported neoliberal reforms since the role of the state in the economy would be very limited. The product markets were liberalised and there was also a shift from 'import substitution' to 'export-oriented' policies (Bhaduri, 1993). During the early 1990s, the Indian economy rapidly opened up. It seems that this was done not only to enforce a cost discipline on the supply side through foreign competition, but also to narrow the differences between domestic and international prices.

The key question arises: What has happened to industrial growth since the economic reforms were undertaken in 1991 in India? After two years of negative growth, growth rates began to increase in 1994. The annual growth rate in the manufacturing sector was $6.4 \%$, which was lower than that during the 1980 s, namely $8.2 \%$. In manufacturing, various industries behaved differently. For instance, consumer durable goods continued to grow fastest but the capital goods industry suffered most. As a result, the annual growth rate of electrical goods declined by nearly $6.7 \%$ between 1991 and 1999. This was not due to a fall in the investment rate but because of increasing import competition, as tariff on imports were substantially reduced during this period.

India's foreign exchange balance started to rise from a very low level in 1991, when the economy was at very critical level. Exports have risen, especially in software and information-related technology. Exports as a percentage of GDP exceeded $10 \%$ for the first time in 1992 and then remained at around 19\%. There was success in both the software and the pharmaceuticals sector and Indian corporations also invested overseas in buying international companies. Since 2007, a number of Indian companies (such as 
Tata, Hindalco etc.) went for acquisition in the United States and various European countries on the strength of massive foreign currency loans at low costs.

According to Panagariya (2004) the surge in industrial growth in India which took place in the 1980s could not be attributed entirely to the economic reforms of 1991 . The 1980s industrial policies could not be sustained over a longer period, as they relied on huge deficit financing and excessive foreign borrowings. According to Basu and Maertens (2007:164) observe: "If India wants to sustain and raise even higher its current growth, the main bottlenecks in the Indian economy will need to be addressed. These are infrastructures such as roads, expensive freight rates, power supply, ports and airports, labour and bankruptcy regulations, and the high level of corruption".

Macroeconomic performance is seen to crucial to industrial growth. Table 2 shows India's macroeconomic changes (average annual \% changes) from 2013-14 to 2018-19. The figures of 2017-18 and 2018-19 are projected data from the OECD. India's rates are projected to remain above $7 \%$ per annum, while the consumer price index is expected to remain low. Also, imports will remain higher than exports (see Table 2).

Table 2. India's macroeconomic indicators and projections (annual \% changes), from 2013-14 to $2018-19$.

\begin{tabular}{lcccccc}
\hline Indicators & $2013-14$ & $2014-15$ & $2015-16$ & $2016-17$ & $2017-18^{*}$ & $2018-19 *$ \\
\hline Real GDP* & 6.6 & 7.2 & 7.6 & 7.0 & 7.3 & 7.7 \\
Consumer Price Index (CPI) & 9.4 & 5.8 & 4.9 & 4.8 & 5.0 & 4.6 \\
Wholesale Price Index (WPI) & 6.0 & 2.0 & -2.5 & 2.8 & 4.0 & 4.2 \\
Fiscal Balance (\% of GDP) & -6.7 & -6.5 & -7.2 & -7.0 & -6.7 & -6.4 \\
Current Account Balance (\% & -1.7 & -1.3 & -1.1 & -0.8 & -0.9 & -0.9 \\
of GDP) & & & & & & \\
Gross Fixed Capital Formation & 3.4 & 4.9 & 3.9 & 0.4 & 4.3 & 7.3 \\
Total Domestic Expenditure & 2.0 & 6.9 & 8.0 & 5.4 & 7.5 & 7.9 \\
$\begin{array}{l}\text { Exports of Goods \& Services, } \\
\text { National Accounts Basis }\end{array}$ & 7.8 & 1.7 & -5.2 & 4.5 & 4.6 & 5.2 \\
$\begin{array}{l}\text { Imports of Goods \& Services, } \\
\text { National Accounts Basis }\end{array}$ & -8.2 & 0.8 & -2.8 & -2.3 & 5.4 & 6.3 \\
$\begin{array}{l}\text { Net Exports, Contribution to } \\
\text { Growth of Real GDP }\end{array}$ & 4.5 & 0.2 & -0.5 & 1.5 & -0.2 & -0.2 \\
\hline
\end{tabular}

Source: OECD, 2017:12. http://www.oecd.org/eco/surveys/economic-survey-india.htm.

Note: *GDP measured in market prices (i.e., at factor costs plus indirect taxes, minus subsidies).

With regard to the comparison between the manufacturing sector performance in the pre-and post-reform period, Nagaraj (2006) noted: "The growth rates for the period before reforms (1980-81 and 1991-92) are 7.4\% and 7.6\% per year respectively[...] However, there are no statistically significant changes in the trend growth rate of the registered manufacturing GDP after reforms" (Nagaraj, 2006: 180).

The Economic Survey (2014) states that growth is the prerequisite for achieving several economic objectives including economic development, industrialisation and improving the living conditions of ordinary people. Industrial growth has slowed down 
since 2012, export growth has also slowed down and all these factors has adverse impact on the current account balance (as shown in Figure 1)
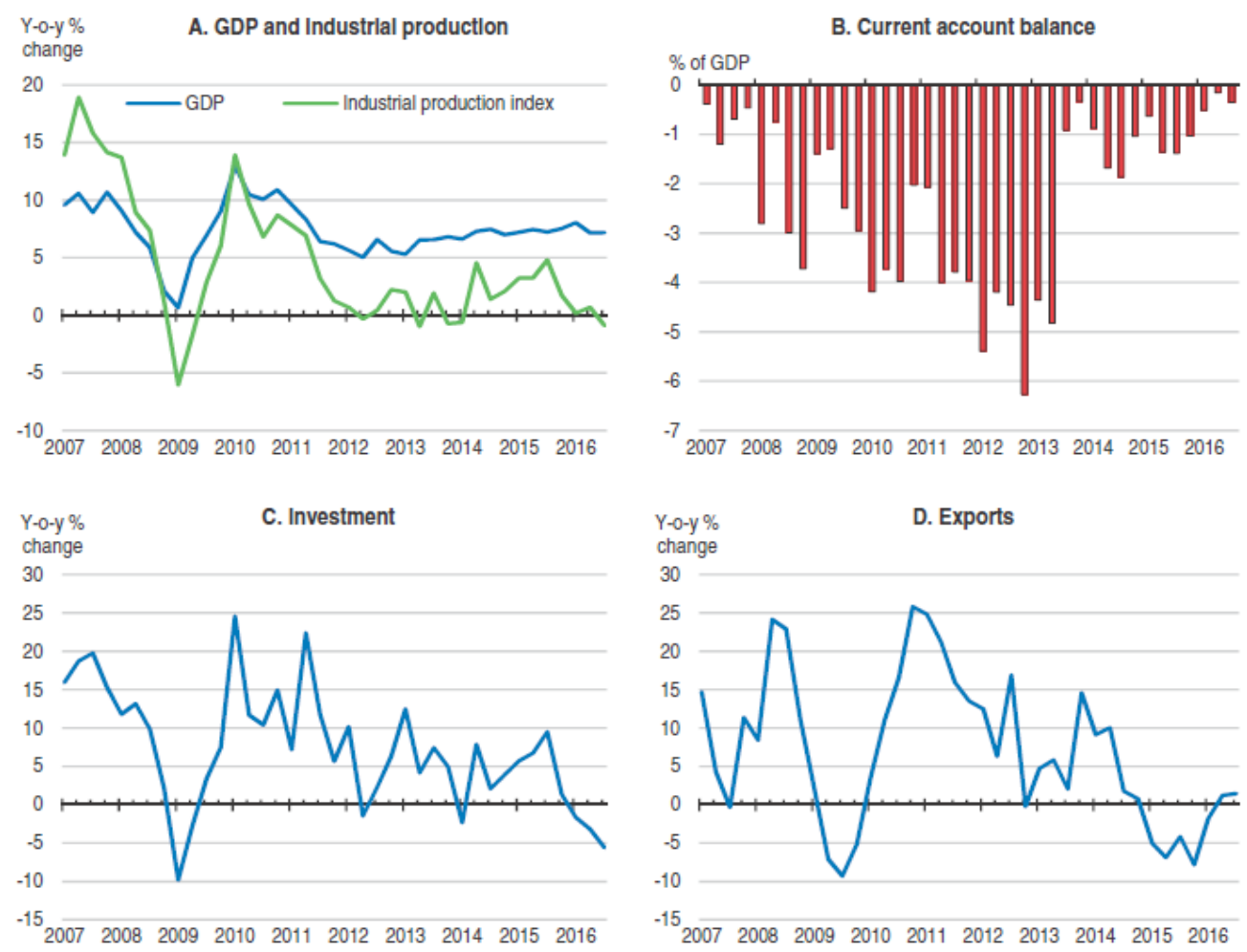

Figure 1. India's macroeconomic developments, 2007-2016

Source: OECD, 2017.

Prior to economic liberalisation, domestic savings were mobilised and invested in the public sector, which relied on domestic markets. But since the adoption of economic reforms, hopes have been pinned upon foreign capital and MNCs to achieve modernisation and productivity growth. However, growing trade deficits in the manufacturing sector clearly show that the manufacturing sector is losing its competitiveness across the range of medium- to high-tech goods. Manufacturing of this kind accounted for only $15 \%$ of India's export earnings in 2010 as against a corresponding figure of $50 \%$ for China (UNCTAD, 2013: 173) whilst resource- and knowledge-based exports account for $25 \%$ of India's total export earnings.

It has been claimed that an increase in the rate of investment necessarily increases the rate of growth of aggregate supply of goods and services (Srinivasan, 2005). But if there is no mechanism in the economy which can generate a corresponding and equivalent growth in aggregate demand, then an increase in the rate of growth in the economy would lead to an increase in unsold goods and services. The intersectoral shift in the workforce from agriculture to manufacturing slowed down during the period 1990 to 1997 and labour productivity in the non-agricultural sector (including manufacturing and services) was nearly four times that in agriculture. It clearly means that this slow-down in the transformation of the workforce implies an immense loss in productivity gains (Siddiqui, 2015a). To regain this loss of momentum in workforce transformation and to ensure better utilisation of surplus labour is crucial, lying at the heart of equity growth in a large agrarian country such as India.

However, India's investment to GDP ratio has been on a downward trend for some years (See Figure 2) and also India's invetment is far below than China. Recently, 
low capacity utilisation and the weak financial position of some corporations have damped corporate investment (Siddiqui and Armstrong, 2017b). Several factors have added to these cyclical factors such as banking system has been weakened by poorly performing public banks, which suffer from high non-performing loans, and also the infrastructure bottlenecks (e.g. frequent power cuts) coupled with the often long land acquisition process, have held back investment, in particular in the manufacturing sector (OECD, 2017).

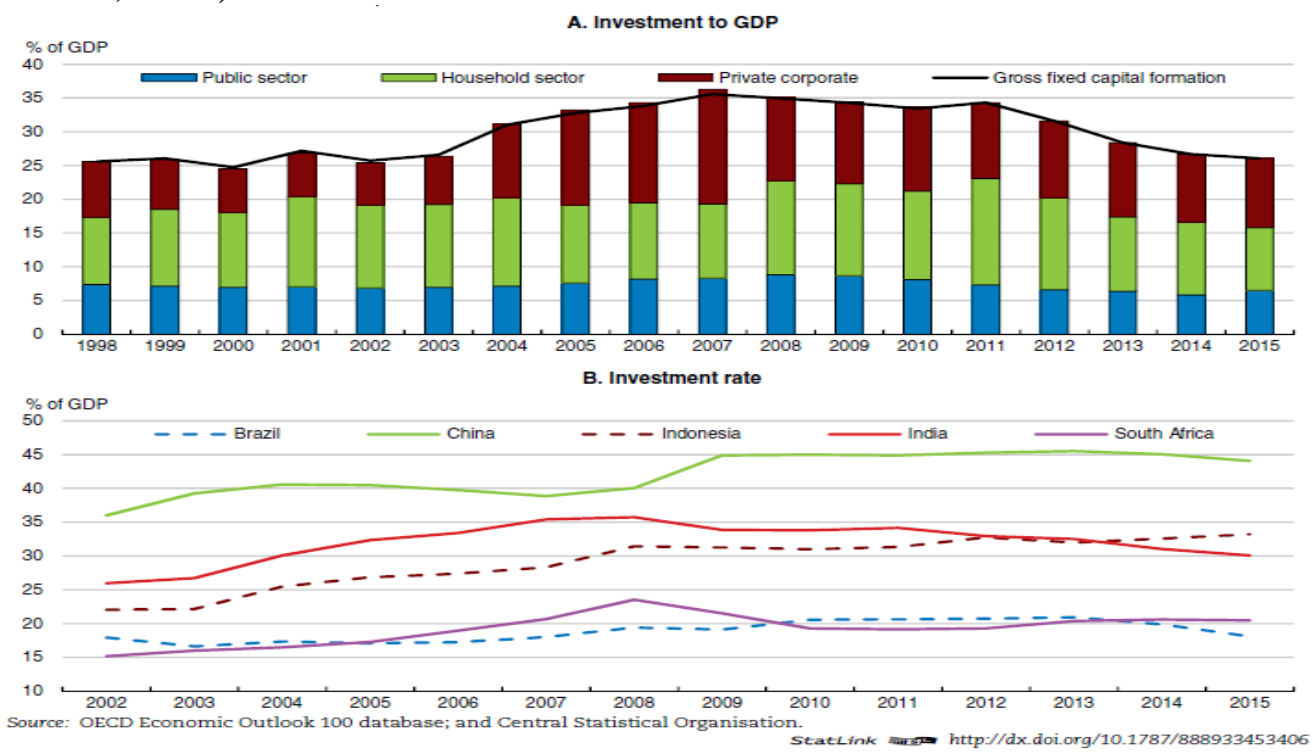

Figure 2: Investment rates in India, 1998-2016.

Source: OECD, 2017; http://dx.doi.org/10.1787/888933453406

India's potential growth is high. According to OECD estimates, it stands at slightly above $7 \%$ in 2016, largely consistent with other estimates (OECD, 2017) However, it has been slightly declining trend since 2012, as the investment to GDP ratio dropped from $34 \%$ in 2011 to $30 \%$ in 2015 (OECD, 2017). Investment is very important for the economy and it is a key factor to achieve stronger long-term growth. It also requires more public investment to reduce infrastructure bottlenecks.

India's experience over the past few decades indicates that corporations are out to make profits by cutting costs, especially the cost of labour. They create more output per worker but not much employment. For example, Tata Steel in Jamshedpur increased its annual production five-fold from 1 million to 5 million tonnes between 1991 and 2006 , but at the same time it reduced its workforce from 85,000 to 44,000 . Similarly, India's record of employment generation has been dismal for over two decades under neoliberal reforms. Despite an annual GDP growth rate of over $7 \%$, growth in employment has been less than $1 \%$.

Moreover, it was expected that an open economy would lead to the availability of cheaper capital goods and machinery, and ultimately would result in the expansion of labour intensive industries, but this did not happen. The crucial point is whether the neoclassical model provides an adequate framework to understand the development process of a huge agrarian country such as India. As Bhaduri argues that, "In the presence of substantially under-utilised labour, an extensive growth strategy may still form an essential element in the early phase of development process [...] indeed there is something strange about so much attention being paid to 'efficient allocation of resources' and the price mechanism while ignoring the blatant inefficiency of massive under-employment" (Bhaduri, 1993: 11). 
Large Indian companies welcomed foreign capital and technology. The IT sector which is highly competitive found their interests would be better served by closer cooperation with global markets. Some small and medium enterprises also welcomed this as they found that the foreign technologies; capital and business organisation in addition to joint ventures with foreign companies would help them to compete with domestic monopolies. For example, increasing the foreign equity limit in Indian telecommunications was supported by Bharti Enterprises, as it helped the company to enter into a successful partnership with Signtel, Warburg Pincus and other overseas companies. India's largest companies also found new opportunities to enter the global market. Another Indian company, for example, Tata valued at US\$ 70 billion in 2015, has transformed itself into an Indian multinational company. Its global sales for 2016 represented more than two-third of its total sales and one-third of its total employees work outside India (Siddiqui, 2017a).

We should not ignore the changing nature of the composition of both Indian and foreign markets. The reasons for the slow growth of industries could also explain lack of job creation. The sectoral shift in favour of services and economic liberalisation means the further opening up of Indian markets has led to the increase in imports of goods especially for the richer sections of society. Increased reliance on exports would mean Indian industries have to produce goods that are in demand on the world market, manufactured using modern technology, which is often labour-saving. Increasing reliance on MNCs, which employ capital saving technology and high import intensity of domestic manufacturing, reduces the employment elasticity of growth.

Industries contributed to $26.9 \%$ to the GDP in India in 1990, which slightly declined to $26.2 \%$ in 2000 whilst in 2010 , it rose slightly to $26.3 \%$. In contrast to this, China's industrial sector contribution was higher than that of India i.e. $41.3 \%$ in 1990 , steadily rising to $45.9 \%$ and $46.8 \%$ in 2000 and 2010 . In the case of the manufacturing sector, the percentage of GDP is almost double in China as compared to that of India (Siddiqui, 2016a). Although exports of manufactured goods have risen in both countries between 1990 and 2010, the rate of this increase was much faster in China than in India. Such differences in the performance of per capita GDP terms could also be found. Since 1990 China has witnessed a sharp rise in GDP per capita, while in India this was more modest. This was largely due to the dramatic expansion of the industrial sector and exports, while India failed to witness any similar rapid expansion in its industrial sector. At present, India's manufacturing sector accounts for $16 \%$ of the GDP and it employs about $1 \%$ of the total workforce (Siddiqui, 2015b). During the period 1990 to 2000 the annual growth of this sector has been $6.8 \%$, while for the same period China's manufacturing sector witnessed double digit growth of $12.8 \%$, which is nearly double that of India (Siddiqui, 2016a).

Here it is important to look at the industrial sectors' contribution to GDP in other developing countries such as in 1960 industries contributed $37 \%$ of the GDP in Brazil, 45\% in China, $19 \%$ in India, $25 \%$ in South Korea and $19 \%$ in Malaysia (Siddiqui, 2012b). By 1985, the figures were: 45\% in Brazil, $43 \%$ in China, 26\% in India, 39\% in South Korea, and 39\% in Malaysia. In 2010, industrial GDP represented 28\% in Brazil, $47 \%$ in China, $27 \%$ in India, 39\% in South Korea and $44 \%$ in Malaysia (Siddiqui, 2016b).

\section{STATE VS. MARKET IN FOSTERING INDUSTRIALISATION}

It is important to examine the choices in industrial policy between the role of state and market. The development of modern industries has been subject to debate 
among academics and policy makers, concerning whether industrial strategy should be based on 'import-substitution' or 'export-led growth'. In the neoclassical model, the role of the state should be minimal, whilst greater reliance is placed on "market forces" (Basu and Maertens, 2007). The mainstream economists advocate for the minimal role of the state in the development of the industrial sector and they largely focus on 'getting the price right' (Krueger, 1987). Such arguments run into difficulties when there is virtually no past evidence to support this model of development. Successful industrialisation in the past was always carried out with active state intervention whenever it was seen necessary in order to achieve suitable outcomes (Reinert, 2007).

However, historical experience for developed countries clearly shows us that state intervention is important to promote industrialisation. For example, in the $19^{\text {th }}$ century the United States had extensive policies in favour of protectionism. Britain also adopted protectionist measures and used state intervention to promote its industrial sector. In the $18^{\text {th }}$ century British policy was characterised by heavy tariffs to protect its domestic industries against the onslaught of cheap foreign goods. Britain had heavy tariffs from 1775 onwards, which continued for a century. The British government levied export duties, which made raw wool more expensive to foreign producers; at the same time it provided tax exemption and monopolies to those who established themselves as wool manufacturers. This continued for nearly a century, followed by a ban on all export of woollen cloth from Ireland from 1699 onwards. The suppression of Ireland's domestic woollen industry was seen as necessary in order to build wool manufacturing in England. The Western countries who today support the free market, in the past saw the active role of the state as essential to achieving desired levels of growth and building a strong industrial sector (Chang, 2010).

Thus, historical evidence concerning successful industrialisation confirms that building an industrial base in the developing countries would require state support, which would also put a limit on imports ((Siddiqui, 2012a). Otherwise the nation in question would be trapped into focusing on exports of raw material and low value products as is the case for the majority of the developing countries, a sector that is characterised by diminishing returns and often over-supply and negative terms of trade. In a broader historical context, Rist argues that, "The historical conditions that would explain the 'lead' of some countries over others cannot enter into the argument, since the 'laws of development' are supposedly the same for all, and 'win their way through with iron necessity' [...] this bracket out the effects of conquest, colonisation, the slave trade, the dismantling of craft production in India, the breaking of social structures, and so on" (Rist, 2009:75).

In order to achieve industrialisation, the question arises whether reliance should be made on state intervention or market forces in the economy. The Prebisch-Singer model argues that government intervention is seen as crucial for successful industrialisation since according to them this would lead to diversification of the economy and output. This is considered a necessary prerequisite for affluence. As a consequence, not only failed to diversify their economy but also unable to draw people away from agriculture into expanding manufacturing sector flourished. Higher growth in the manufacturing sector could lead to higher productivity not only in agriculture but also other industries as well. It has been argued that negative trends in terms of trade acts as an impediment to the economic progress of the developing countries (Singer, 1987; Siddiqui, 2016b).

However, the past experiences of Brazil, China, India and Mexico tell us that the 'import substitution' policy ran into difficulties after some time (Siddiqui, 2015b) This 
was due to a number of reasons like in the name of protection of domestic markets: inefficiency, rent-seeking, and wastefulness of resources flourished. Local producers turned into monopolies and thus were able to charge higher prices than imported prices (Patnaik, 2015).

\section{CONCLUSION}

India was the top manufacturing nation until the British conquest of Bengal. In fact, colonialism degraded the Indian economy and squeezed the incentives for local investment in industry and agriculture. For the majority of the colonial period, Indian agriculture stagnated and foodgrain output fell. The primary goal for the British colonial administration was to extract revenues from the peasantry. From the mid-18th century, India's economy was integrated into the British colonial system which, besides extracting surplus value, also imposed an international division of labour with unequal terms of trade where India was turned into a supplier of primary commodities. During the colonial period, the Indian economy became subservient rather than sovereign in terms of policy matters (Sen, 1981).

The study found that soon after independence in 1947, the Indian government took a number of initiatives to enhance industrial and agricultural development. Initially, these met with some modest success including building key industries, becoming self-sufficient in terms of food production and improving literacy rates. However, the biggest failure was that it did not make any real impression on the country's huge unemployment problems. By the mid-1960s economic growth had begun to falter and the fiscal crisis of the state deepened. Finally, India sought an IMF loan in 1991 to avert balance of payment crisis. In return, India was asked to adopt neoliberal reforms (Patnaik, 2015).

To compare Indian economic policies under neoliberal reforms with those of the previous period under dirigisme would seem to be important, particularly when we consider this comparison in terms of employment expansion. In the period of neoliberal reform, the growth rates accelerated to $7 \%$ annually, but the rate of growth of employment has remained at only $1 \%$, while in the dirigiste period the average growth rate was $3.5 \%$, but the expansion of employment was doubled i.e., $2 \%$ annually.

In fact, in the late 1950s and 1960s the industrial sector did witness a sharp rise. For example, the share of manufacturing in GDP rose from 9\% in 1951 to $16 \%$ in 1961. Indeed, a decade later this share reached $18 \%$ before reaching its peak of $20 \%$ in 1996. However, the industrial share in GDP was still less in comparison to other developing economies, particularly in East Asia. For example, in 1971, the manufacturing share in GDP for South Korea was 25\%, Malaysia 28\%, Thailand 26\%, China 35\% and Brazil $29 \%$ (Siddiqui, 2016a; 2018). The study has argued that India's progress towards industrialisation has been disappointing and the optimism that foreign capital and technology would bring efficiency and boost growth in manufacturing has largely been proven unfounded. In fact, manufacturing is very important for a country like India, where rapidly growing manufacturing, besides earning foreign capital, can utilise labour, increase productivity and incomes through linkages and spill-overs into other sectors.

However, since neoliberal reforms were undertaken in 1991, the agriculture sector hardly saw any benefits and, during this period, its growth rates were negligible (Siddiqui, 2010). The pursuit of neoliberal economic policies has led to the withdrawal of the state role in assisting farmers in particular and the rural sector in general, and is instead promoting the interests of global financial capital, with which the Indian 
corporate capital is closely integrated. Despite the fact that the majority of the country's population has not witnessed any improvement in its living conditions, the government nevertheless celebrates this as a "great achievement"; it has completely ignored economists such as John Stuart Mill when he said that he did not mind a zero growth rate if workers are better off in such a stationary state than in a growing economy. For him, improvements in workers' real incomes should take priority over high GDP growth rates. On this account, the statistics reveal that since the adoption of neoliberal policies half of India's population has witnessed stagnation in its real per capita income.

The study concludes that twenty-five years have passed since the neoliberal economic reforms were launched in India, but industrial growth has still not witnessed rapid expansion, especially in manufacturing areas. And it seems that neoliberal policies have failed to create jobs and thus improve the living conditions of significant proportion of the population. Therefore, to combat these problems certainly requires effective government policy intervention, especially in areas such as education and health sectors, which could ultimately have very positive effects on industrial growth and productivity.

\section{REFERENCES}

Amsden, A. (2003). The Rise of "The Rest" - Challenges to the West from the Late Industrialising Economies, London: Oxford University Press.

Anstey, V. 1957. The Economic Development of India, London: Longmans Green and Co.

Bagchi, A. K. (1985). The Political Economy of Underdevelopment, London: Cambridge University Press.

Bagchi, A. K. (1976). "De-industrialisation in India in the $19^{\text {th }}$ Century: Some Theoretical Implications", Journal of Development Studies, Vol. 12 (2), pp. 135164.

Basu, K. and A. Maertens. (2007). "The Patterns and Causes of Economic Growth", Oxford Review of Economic Policy, Vol. 23 (2), p. 143-167. DOI:10.1093/oxrep/grm012

Bhaduri, A. (1993). "Orthodox Development Theories and their Application to LessDeveloped Countries", in Gianni Vaggi (ed.) From Debt Crisis to Sustainable Development: Changing Perspectives in North-South Relationship, London: St. Martin's Press.

Central Statistical Organisation (CSO). (2014). National Accounts Statistics of India, New Delhi: Ministry of Finance, Government of India.

Chang, Ha-Joon. (2010). Bad Samaritans; The Myth of Free Trade and the Secret History of Capitalism, London: Bloomsbury Publishing.

Das, G. (2006). "The India Model”, Foreign Affairs, Vol. 85 (4), p.2-16. https://www.foreignaffairs.com/articles/asia/2006-07-01/india-model

Dutt, R.C. (1902) Economic History of India under early British Rule, Vol. 1, London: Kegan Paul

Economic Survey. (2014). Government of India, New Delhi: Ministry of Finance. doi: http://dx.doi.org/10.1787/eco_surveys-ind-2014-en

Economist. (2007). "India on Fire", February1, London. doi: https://www.economist.com/briefing/2007/02/01/india-on-fire

Habib, I. (1984). "Studying a Colonial Economy Without Perceiving Colonialism", Social Scientist, December, p. 5-27. 
Habib, I. (1975). "Colonisation of Indian Economy, 1757-1900”, Social Scientist, Vol. $3(8)$.

Kaldor, N. (1967). Strategic Factors in Economic Development, Ithaca, New York: Cornell University Press.

Kalecki, M. (1971). "Class Struggle and the Distribution of National Income" Kyklos, 24 (1):1-9, February. DOI: 10.1111/j.1467-6435.1971.tb00148.x

Krueger, A. (1987). "Rent Seeking”, in Eatwell, J, Milgate, M. and Newman, P. (eds.) The New Palgrave: a dictionary of economics, 4:147-9, London: Macmillan.

Lewis, A.W. (1954). Economic Development with Unlimited Supplies of Labour, Vol. 22 (2):400-451, May, Manchester School, UK.

Maddison, A. (1995). Monitoring the World Economy, 1820-1992, Development Centre of the OECD, Paris: OECD.

Nagaraj, R. (2017). "Economic Reforms and Manufacturing Sector Growth: Need for Reconfiguring the Industrialisation Model" Economic and Political Weekly. LII (2): 61-68, January 14.

Nagaraj, R. (2006). Aspects of India's Economic Growth and Reforms, New Delhi, Academic Foundation.

Nayyar, D. (2006). "Economic Growth in Independent India: Lumbering Elephant or Running Tiger", Economic and Political Weekly, 15 ${ }^{\text {th }}$ April, p. 1451-1458.

OECD. (2017). Economic Surveys: India, Paris: OECD. https://www.oecd.org/eco/surveys/INDIA-2017-OECD-economic-surveyoverview.pdf. (accessed on 10 May 2018).

Panagariya, A. (2004). "Growth and Reforms during the 1980s and 1990s", Economic and Political Weekly, pp. 2581-94, June 19.

Patnaik, P. (2015). “The Nehru-Mahalanobis Strategy”, Social Scientist 43 (3-4): 3-10.

Patnaik, P. (1979). "Industrial Development in India since Independence", Social Scientist, 7(11):3-19, June.

Raj, K.N. (1986). "Growth and Stagnation in Indian Industrial Development", Economic and Political Weekly, XXI (5-7), February, Annual Number.

Reinert, E. (2007). How the Rich Countries got Rich and Why Poor Country Stay Poor, New York: Carroll \& Graf.

Rist, G. 2009. The History of Development, $3^{\text {rd }}$ edition, New Delhi: Academic Foundation.

Rodrik, Dani. 2016. "Premature Deindustrialization", Journal of Economic Growth, 21: 1-33. DOI: 10.1007/s10887-015-9122-3.

Sen, Amartya. 1981. Poverty Famines: An Essay on Entitlement and Deprivation, New York: Oxford University Press.

Sen, P. 2007. "Capital Inflows, Financial Repression, and Macroeconomic Policy in India since the Reforms", Oxford Review of Economic Policy, Vol.23 (2), p.292310.

Siddiqui, K. 2018. "Hindutva, Neoliberalism and the Reinventing of India", Alternatives Sud (in French) 25 (1): 39-60. ISBN: 978-2-84950-662-2.

Siddiqui, K. 2017a. "Financialization and Economic Policy: The Issues of Capital Control in the Developing Countries", World Review of Political Economy 8 (4): 564-589, winter, Pluto Journals. DOI: 10.13169/worlrevipoliecon.8.4.0564.

Siddiqui, K. and P. Armstrong. 2017b. "Capital Control Reconsidered: Financialization and Economic Policy", International Review of Applied Economics 1-19, March. doi.org/10.1080/02692171.2017.1375464 
Siddiqui, K. 2016a. "Will the Growth of the BRICs Cause a Shift in the Global Balance of Economic Power in the 21st Century?" International Journal of Political Economy 45(4):315-338, Routledge Taylor \& Francis. http://dx.doi.org/10.1080/08911916.2016.1270084.

Siddiqui, K. 2016b. "International Trade, WTO and Economic Development", World Review of Political Economy, 7(4):424-450, winter, Pluto Journals.

Siddiqui, K. 2015a. "Agrarian Crisis and Transformation in India", Journal of Economics and Political Economy, 2 (1):3-22. ISSN: 2148-8347, JEL. E24, F50, F55.

Siddiqui, K. 2015b. "Perils and Challenges of Chinese Economic Development", International Journal of Social and Economic Research 5 (1):1-56, ISSN: 22496270. DOI : 10.5958/2249-6270.2015.00001.X

Siddiqui, K. 2014a. "Contradictions in Development: Growth and Crisis in Indian Economy", Economic and Regional Studies, 7 (3):82-98, ISSN 2083-3725.

Siddiqui, K. 2014b, "Modernisation and Displacement of Rural Communities in India", Journal of Social Business, 4 (2-3):3-27. ISSN 2045-1083.

Siddiqui, K. 2013. "Experiences of Developmental State in India and Taiwan", Think India Quarterly, 16(4):91-121, December. ISSN: 097-1260.

Siddiqui, K. 2012a. "Developing Countries Experience with Neoliberalism and Globalisation" Research in Applied Economics, Vol.4 (4) December, pp.1237.DOI: $10.5296 /$ rae.v4i4.2878

Siddiqui, K. 2012b. "Malaysia's Socio-Economic Transformation in Historical Perspective", International Journal of Business and General Management, Vol.1 (2), November, pp. 21-50. ISSN: 2319-2267

Siddiqui, K. 2010. "The Political Economy of Development in Singapore", Research in Applied Economics, Vol.2, (2), pp.1-31, ISSN: 1948-5433.DOI: http://dx.doi.org/10.5296/rae.v2i2.

Siddiqui, K. 2009. "The Political Economy of Growth in China and India", Journal of Asian Public Policy, Vol.1, (2), March, p.17-35, ISSN 1751-6234

Siddiqui, K. 1998. "The Export of Agricultural Commodities, Poverty and Ecological Crisis: A Case Study of Central American Countries", Economic and Political Weekly, Vol. 33 (39), $26^{\text {th }}$ September, pp. A128-A137.

Siddiqui, K. 1996. "Growth of Modern Industries under Colonial Regime: Industrial Development in British India between 1900 and 1946", Pakistan Journal of History and Culture, 17 (1):11-59, January.

Siddiqui, K. 1991. "Recent Neoliberal Economic Reforms in India", Information, (in Danish), $19^{\text {th }}$, September, Copenhagen, Denmark

Siddiqui, K. 1990. "Historical Roots of Mass Poverty in India", in Thayer, C.A. et al,(eds.) Trends and Strains, p. 50-76, New Delhi: Continental Publishing House.

Singer, H.W. (1987) "The Terms of Trade and Economic Development", in Eatwell, J, Milgate, M. and Newman, P. (eds.) The New Palgrave: a dictionary of economics, Vol. 4, p.626-8, London: Macmillan

Srinivasan, T.N. (2005) Comments on from Hindu Growth to Productivity Surge: The mysteries of Indian growth transition, IMF Staff Papers, Vol. 52 (2), Washington DC: IMF.

Thorner, D. 1962. "De-industrialisation in India 1881-1931", in Thorner, D. and Thorner, A. (eds.), Land and Labour in India, Bombay: Asia Publishing House.

UNCTAD. 2013. Trade and Development Report, New York: United Nations.

World Bank. 2006. India's Employment Challenges, Washington DC, The World Bank. 